\title{
Environmental impact analyses of gas flaring in the Niger delta region of Nigeria
}

\author{
E.C. Ubani ${ }^{1}$ and I.M. Onyejekwe ${ }^{2}$ \\ ${ }^{1}$ Department of Project Management Technology, Email: drecubani@yahoo.com \\ ${ }^{2}$ Department of Petroleum Engineering, Email: oronst@yahoo.com \\ Federal University of Technology Owerri-Nigeria
}

\begin{abstract}
Gas flaringis the burning of natural gas and petroleum hydrocarbons in flare stacks by upstream oil companies in oil fields during operations. Gas flaring is the singular and most common source of global warming and contributes to emissions of carbon monoxide, nitrogen (II) oxide and methane which have the propensity of causing environmental pollution and ecological disturbances or destruction. This research explore and presents a method of analysing the environmental impact of gas flaring in the Niger Delta so to provide the data required for the complete analysis and evaluation of the various observed and noted health and environmental effects of gas flaring in Niger Delta. The major environmental impacts considered in the study are environmental pollution, and ecological disturbance or destruction. Several visitations to the neighbouring communities adjacent to most gas flare locations were carried out to ascertain any existence of common environmental hazards. Data was gathered through a well designed and articulating oral and written questionnaires, direct and first-hand observation of their environment, and comprehensive interview sessions with community heads (royal authorities where possible), patients and youth. Different samples at various proximities from the gas flare locations were taken and measurements and experimentations were meticulously carried out. The result obtained in this research shows a marked trend as all the parameters considered showed a gradient away from the flare point in all the flow stations such as soil pH changing from acidic (4.0-4.2) to near neutral (6.4-6.6) away from the flare points and the average low soil moisture content of $(17 \%-23 \%)$ as against $40 \%$ for the $(10 \mathrm{~m}$ and $20 \mathrm{~m})$ and control distance. The quantity of carbon emitted by these flare is about 2525000.00 tonnes of carbon per day. These values portray a bad omen for the affected communities. This study recommends that gas flaring should be seen as violet action against the people and that the flared gas should be channelled to meeting the ever increasing demand for energy in the industrial sector of the economy.
\end{abstract}

Keywords: Gas flaring, $\mathrm{CO}_{2}$ emissions, Natural gas, Associated gas, Non Associated gas, Greenhouse gas.

\section{INTRODUCTION}

Natural gas is a subcategory of petroleum that is a naturally occurring complex mixture of hydrocarbon with a minor amount of nonhydrocarbon gases. The discovery and extraction of natural resources have brought different consequences to countries that are endowed with such resources. While some of these nations have become economically strong and self sustaining, others have been drawn into serious economic hardships and conflicts. Proponents of the resource curse, project have it that the citizens of these countries rather suffer from abject poverty, environmental damages, pollutions, diseases, illiteracy and score very low on the United Nation's Human Development Index (UNDP, 2006).Gas flaring contributes to climate change, which has serious implications for both Nigeria and the rest of the world. Nigeria is one of the highest emitter of greenhouse gases in Africa and among the highest $\mathrm{CO}_{2}$ emitters in the world (GGFR, 2002; lyayi, 2004). The Niger Delta region, where Nigeria current large oil and gas resources are located, to with the Niger Delta as the unifying feature has remained a source of global interest. With openness to the Atlantic Ocean and watercourses with access to the sea and rivers such as the Benue and Niger Rivers, the Niger Delta embodies some of the major coastal upwelling sub-ecosystems of the world and is an important centre of marine biodiversity and marine food production ranked among the most productive coastal and offshore waters in the world. However, pollution from domestic and industry sources, overexploitation of oil and gas resources and poorly 
planned and managed communities and coastal developments and near-shore activities are resulting in a rapid degradation of vulnerable land, coastal and offshore habitats and shared living marine resources of the region putting the economies and health of the populace at risk. The deterioration in water and air quality (chronic and catastrophic) from land and seabased activities (especially flaring/power plants), agricultural, urban and domestic sewage run-off, eutrophication and gas flaring have been identified as a major Tran boundary environmental problem by communities in the region.

Nigeria as a nation is reputed to as a major oil producer. In addition, the nation's hydrocarbon reserve features more gas than crude oil. Estimated at 185 trillion cubic feet, Nigeria's natural gas reserves are rated as the seventh in the world and the largest in Africa (EIA, 2006). The nation's gas reserve is distributed between associated gases (AG) and non-associated gas (NAG). Gas flaring started at the end of the colonial rule. Flaring of associated gas is the process of burning of surplus combustible vapours from an oil well, either as a means of disposal or as a safety measure to relieve well pressure. Gas flaring contributes to emissions of carbon monoxide, Nitrogen (II) oxide and methane which are estimated between 1 to $4 \%$, of the total emissions from all sources of noise, unwanted heat and light, affecting nearby communities and surroundings flora and fauna. Nigeria flares $50 \%$ of her total associated gas produced which is about 850 billion cubic feet per year (Bcf/y).Because of an undeveloped Internal Gas Market; about 52\% of current Gas production of $6 \mathrm{bscf} / \mathrm{d}$ is flared. Nigeria flares the second largest volume of gas behind Russia, which account for about $11 \%$ of the world's total flared volume. The volume of gas flared by Nigeria per annum is more than enough to power the nation's energy demand. Despite Nigeria's huge gas reserves, the country still suffers chronic energy shortages. Gas flaring expends huge amount of energy and causes health and environmental degradation. The environmental and human health of the people in the Niger Delta region has frequently been a tertiary consideration for the oil companies. Neither the Federal Environmental Protection Agency (FEPA) nor the Department of Petroleum Resources (DPR) has implemented anti flaring policies for excess associated gases nor have they monitored the emissions to ensure compliance with standards since 1988 (Manby, 1999). Nigerian gas flares emit as many green house gases as 18 million metric tons, and release toxic substances in the areas, damaging both the environment and the health of the people in the Niger Delta. It causes acid rain, which acidifies lakes and streams and also damages the environment (Watts, 2001). The World Bank report towards the development of an environmental action plan for Nigeria in 1990 highlighted the environmental cost of the present unsustainable practices in the development activity of the country. The report estimated that over US $\$ 5$ billion is lost annually in the long term due to activities whose negative impact could have been avoided if environmental impact assessment was carried out. It should be noted that these losses are virtually irreversible and beyond mere economic calculation. Chilaka (2009), from his study stated that the Nigeria gas market lacked adequate infrastructure to produce natural gas and that a considerable quantity of the produced gas is flared. He submitted that $94.9 \%$ of produced gas was flared in 1978 and about $79.2 \%$ was flared in 1984. Currently, Nigeria is flaring about $40 \%$ of produced gas and re-injecting $12 \%$ to enhance oil recovery (Onyekonwu, 2008).Botkin and Keller, 1998 in their work to find out the effect of gas on moisture content conducted some experiment on selected soil sample using the method of ALPHA (1985). Their obtained result shows that moisture content increased away from the flare and then concluded that the low moisture content close to the flaring point is a direct effect of heat. Amund et-al 1987 and Bezharauh et-al 1994 in their respective work on the effect of gas flaring, have implicated pseudomonas as the major crude oil degrader.

\section{MATERIALS AND METHODS}

First, comprehensive lists of all gas flare locations were made. Several visitations were made to most of the various under listed gas flare locations in a bid to achieve my mentioned objectives. Data was gathered through a well designed and articulating oral and written questionnaires, direct and first-hand observation of their environment (landed and water bodies) were made. Different samples at various proximities from the gas flare locations were taken and measurements and experimentations meticulously carried out. The parameters monitored at each sampling location included: Rain water from the flares, Soil temperature, Noise level Soil pH, Soil microbes and Soil moisture content. Standard measurements for each parameter were carried out as follows:

Rain Water Analysis: Clean acid-free glass bottles were used to collect bulk samples of rain that had fallen during the preceding week. The samplers were 
placed at distances of $500 \mathrm{~m}, 1000 \mathrm{~m}$, and $5000 \mathrm{~m}$ from the flare point. The funnel was covered with a plastic net to prevent collection of windblown debris. Each bottle was placed on a stand $1.3-1.5 \mathrm{~m}$ above ground level. The collected samples were analyzed in accordance with cations anions and trace metals (as recommended by DPR and Fed Min of Environment)

Soil Temperature Measurements: The temperature of each soil sample was determined with Mercury-inglass thermometer, which was placed $2-3 \mathrm{~cm}$ into the soil. The thermometer was left for 5 minutes to stabilize and read before withdrawal. This was done at the site of collection.

Soil Moisture Content Measurement: The ALPHA (1985) method was used to determine the moisture content of each soil sampled. $10 \mathrm{~g}$ of each soil sample was heated in a hot air for $8-12 \mathrm{hrs}$ at $80^{\circ} \mathrm{C}$ until a constant weight was obtained. The difference between the initial weight and the consistent final weight obtained was taken as the weight of the moisture.

Soil pH Measurement: The $\mathrm{pH}$ of the various soil samples was determined from supernatant obtained after 1:1 (w:v) mixture of the soil samples were made with sterile distilled de-ionized water. The $\mathrm{pH}$ was determined using a PYE UNICAM model 291mkz pH meter with a combined glass electrode.

Soil Microbes: Effects of gas-flaring on soil bacterial spectrum were investigated using culture techniques and some ecological factors. Soil samples were collected from three spots of each of the stations. These were $10 \mathrm{~m}, 100 \mathrm{~m}$ and $200 \mathrm{~m}$ away from each flare site and a control taken much outside the flow station area. Ten fold serial dilution with sterile physiological saline as diluents was carried out with each soil sample collected and inoculated on nutrient agar (NA), mineral salt agar (MSA) and McConkey agar (MCA) using the spread plate technique. Microbial species observed were subcultured to obtained pure isolates. These were further subjected to macroscopic, microscopy (after starring) and biochemical tests for characterization and identification according to Chessbrough (1987), Cowan and Steel (1976).

Noise Level: Noise levels at the various distances from the flare tip were measured using the Aweighted scale of a decibel meter. Measurements were taken for 5 minutes at each and the range of the noise level was noted and the true mean was computed. Various operational processes that contributed to the noise level at each flow-station and lor gas plants were noted. Measurements were carried out upwind, downwind, and crosswind of the flare. Noise levels were also measured near pumps and power generators at the flow stations and/or gas plants.

\section{RESULTS AND DISCUSSION}

The results on the analysis carried out on rain water to determine the effect of gas flaring are shown on Table 1 and Fig. 1.The results show that the $\mathrm{pH}$ values were generally below 5.6 (WHO 1970 limit for rain acidity) for many of the gas flare locations, hence a water-borne diseases prevalence and massive destruction in aquatic life recorded in these communities. However, on a few occasions, $\mathrm{pH}$ values were greater than 5.6 for rainwater samples collected from some other locations e.g. locations A2,A5, F2 e.t.c. Rainwater samples collected during dry seasons were more acidic than those collected during rainy seasons. This can be explained by the fact that acids formed in the atmosphere with pollutants $\left(\mathrm{HO}_{\mathrm{X}}+\mathrm{H}_{2} \mathrm{O} \rightarrow \mathrm{HNO}_{3}\right.$ \& $\mathrm{SO}_{\mathrm{x}}+\mathrm{H}_{2} \mathrm{O} \rightarrow$ $\mathrm{H}_{2} \mathrm{SO}_{4}$ ) are likely to be more diluted during the rainy season than dry season.

Soil temperature, $\mathrm{pH}$ and moisture content: The results on the investigation carried out on soil temperature, ph and moisture content measurement are shown on Table 2 and Fig. 2 respectively.

Soil Temperature: The result from Table 2 shows that the closer a sampling point was to the flare, the higher the soil temperature. This high temperature affects the survival of microbes and germination of plants. Beyond $100 \mathrm{~m}$ from the fare tip, the soil temperature was more strongly influenced by vegetation cover and the moisture content, rather than the presence of the flare or even insulation. The soil temperature taken in the morning was approximately $1^{\circ} \mathrm{C}$ lower than that taken late afternoon or evening. Effect of vegetation cover was found to lower the soil temperature by as much as $4^{\circ} \mathrm{C}$.

The Soil Ph: The results from Table 2 and Fig. 2 show that $\mathrm{pH}$ values, changed from acidic $(4.0-4.2)$ to near neutral $(6.4-6.6)$ away from the flare point. The low $\mathrm{pH}$ values at the flare points could be attributed to the acidic oxides produced by the flaring. Both the lower $\mathrm{pH}$ and higher aluminum concentrations in surface water that occur as a result of acid rain can cause damage to fish and other aquatic animals. At pHs lower than 5 most fish eggs will not hatch and lower pHs can kill adult fish. As lakes and rivers become more acidic biodiversity is reduced. Acid rain has eliminated insect life and 
some fish species over the years due to these gas flaring and dangerous gaseous emissions.

Table 1: The pH (Average) of rainwater sample taken from various gas flare locations and the W.H.O limit

\begin{tabular}{|c|c|c|c|}
\hline COMPANY & Location & $\mathrm{pH}($ Average $)$ & $\begin{array}{c}\text { W.H.O. } \\
\text { Minimum } \mathrm{pH} \\
\text { limit }\end{array}$ \\
\hline \multirow[t]{7}{*}{$A$} & $\mathrm{~A} 1$ & 3.04 & 5.6 \\
\hline & $\mathrm{A} 2$ & 6.06 & 5.6 \\
\hline & $\mathrm{A} 3$ & 4.14 & 5.6 \\
\hline & A4 & 5.13 & 5.6 \\
\hline & $\mathrm{A} 5$ & 6.81 & 5.6 \\
\hline & $\mathrm{A} 6$ & 4.44 & 5.6 \\
\hline & A7 & 4.13 & 5.6 \\
\hline \multirow[t]{4}{*}{ B } & B1 & 5.09 & 5.6 \\
\hline & B2 & 5.75 & 5.6 \\
\hline & B3 & 3.15 & 5.6 \\
\hline & B4 & 6.19 & 5.6 \\
\hline \multirow[t]{3}{*}{$\mathrm{C}$} & $\mathrm{C} 1$ & 4.82 & 5.6 \\
\hline & $\mathrm{C} 2$ & 5.26 & 5.6 \\
\hline & $\mathrm{C} 3$ & 3.06 & 5.6 \\
\hline $\mathrm{D}$ & D1 & 5.27 & 5.6 \\
\hline \multirow[t]{2}{*}{$\mathrm{E}$} & E1 & 4.35 & 5.6 \\
\hline & E2 & 5.18 & 5.6 \\
\hline \multirow[t]{3}{*}{$F$} & $\mathrm{~F} 1$ & 4.34 & 5.6 \\
\hline & $\mathrm{F} 2$ & 7.56 & 5.6 \\
\hline & F3 & 7.63 & 5.6 \\
\hline$G$ & $\mathrm{G} 1$ & 5.64 & 5.6 \\
\hline \multirow[t]{3}{*}{$\mathrm{H}$} & $\mathrm{H} 1$ & 5.45 & 5.6 \\
\hline & $\mathrm{H} 2$ & 3.55 & 5.6 \\
\hline & $\mathrm{H} 3$ & 6.23 & 5.6 \\
\hline
\end{tabular}

Moisture Content: The results from Table 2 and Fig. 2 above show that moisture content also increased away from the flare site. The lowest soil moisture content was observed at $10 \mathrm{~m}$ distance from the flare site and $200 \mathrm{~m}$ having at least higher percent while the control had the highest percent of moisture in the soil. As expected, the hottest spot was nearest to each flare jet and it gradually decreased away from the flare point. The heat produced from the flaring point is highest at the flare point as expected. The low moisture content close to the flaring point is a direct effect of the heat. All the soil samples examined had the least moisture content in soil at $10 \mathrm{~m}$ followed by $100 \mathrm{~m}$. The $200 \mathrm{~m}$ soil samples and controls had higher moisture content.

Bacteria Counts: The result on the bacteria load count is summarized on Table 3 . The result from Table 3 shows that bacterial load of total heterotrophic bacterial count (THBC), Petroleum degrading bacterial count (PDBC) and Total coliform count (TCC) also increased away from the flare points in nearly all the communities. The bio load from the $10 \mathrm{~m}$ samples were the least, followed by the $100 \mathrm{~m}$ and the $200 \mathrm{~m}$ samples. The difference between $200 \mathrm{~m}$ and the control in each station examined was not significant. Gas flaring affected the oil degrading bacterial species as values obtained from the $10 \mathrm{~m}$ samples were the least. The most affected by the Gas flaring was the coliforms. Total coliforms counts were seriously low for the $10 \mathrm{~m}\left(0.1 \times 10^{2}\right.$ to $\left.0.4 \times 10^{2} \mathrm{cfu} / \mathrm{g}\right)$ and $100 \mathrm{~m}$ $\left(1.6 \times 10^{3}\right.$ to $\left.2.1 \times 10^{3} \mathrm{cfu} / \mathrm{g}\right)$ samples. However, there was a sharp increase at $200 \mathrm{~m}$ samples (3.3 $X$ $10^{4}$ to $1.1 \times 10^{5} \mathrm{cfu} / \mathrm{g}$ ) which was not much different from the values obtained in the controls $\left(3.9 \times 10^{4}\right.$ to $2.3 \times 10^{5} \mathrm{cfu} / \mathrm{g}$ ).

Among bacterial species, only three Pseudomonas, and Bacillus species were found $10 \mathrm{~m}$ away from the flare. Prescot et al. (1999) and Chessbrough (1987) stated that Bacilli are good spore formers hence can survive very harsh environmental conditions like in the $10 \mathrm{~m}$ samples. Similarly, Pseudomonas has been implicated as the major crude oil degrader. The end result of less bacteria counts in the soil is the slow biodegradation of organic matters that will sustain soil quality for good yield of agricultural produce

Noise Level: The noise levels at all the locations were monitored and the result presented on table 4 as shown below. Noise levels at most facilities were generally very close to the DPR/FEPA limit. However, exceptional cases are the noise levels at $A 1$ and $F 3$ flow station and gas plant (86.5) and noise levels measured at distances very close to pumps and generators (93.6-96.1 dBA). These values are however lower than the upper limit of the Nigerian regulatory body (DPR). Continuous exposure to noise at such levels eventually leads to hearing loss unless protective equipment is used, and unfortunately, indigenes don't put on Personnel Protective Equipment (PPE). 
Am. J. Sci. Ind. Res., 2013, 4(2): 246-252

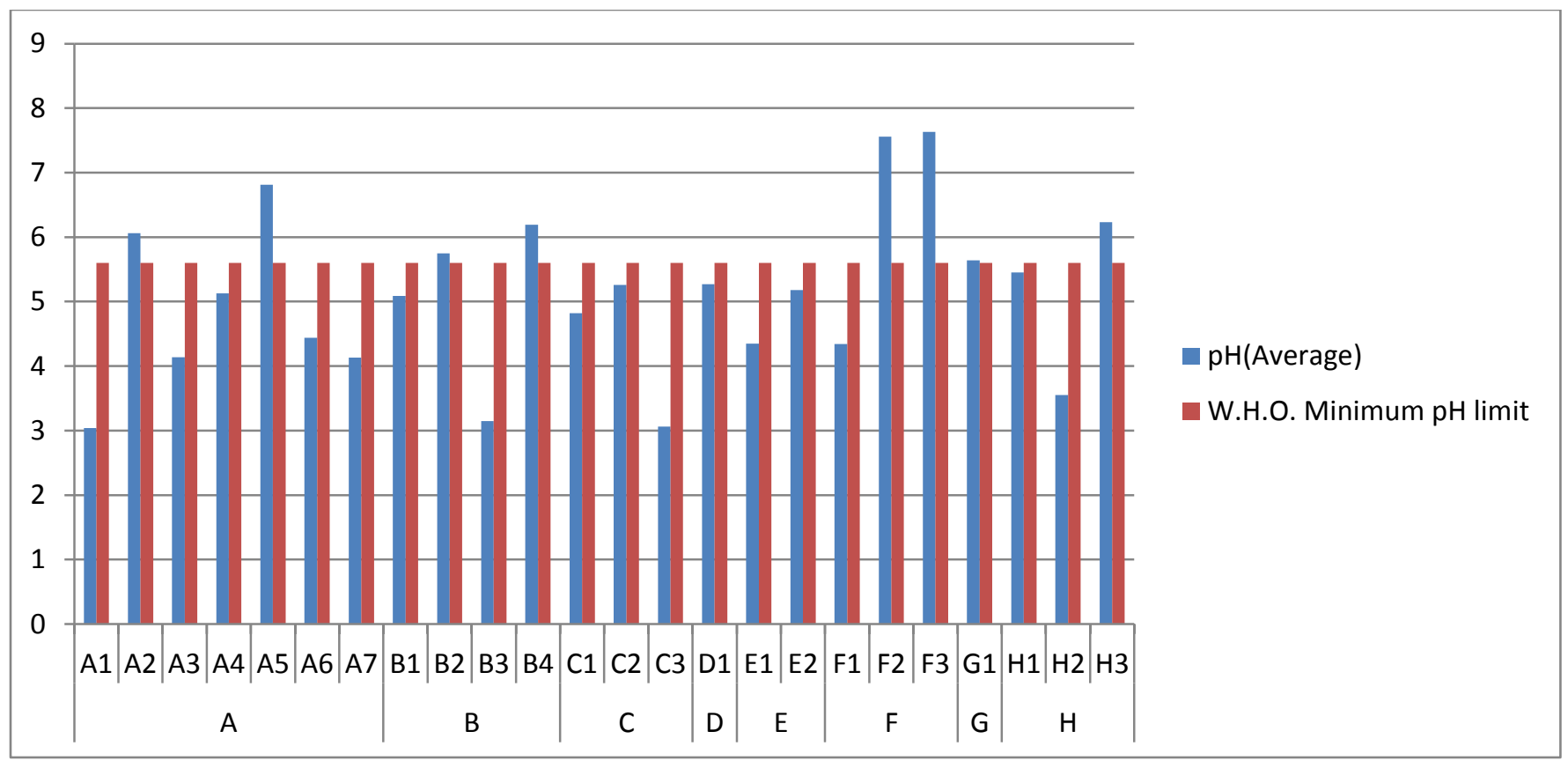

Fig 1: The Average pH of rainwater samples taken from the above gas flare locations.

Table 2: Temperature, $\mathrm{pH}$ and Moisture Content of the various soil samples

\begin{tabular}{|c|c|c|c|c|c|c|c|c|c|c|c|c|}
\hline \multirow{2}{*}{$\begin{array}{l}\text { Distance } \\
\text { from flare } \\
\text { Point }\end{array}$} & \multicolumn{3}{|c|}{ A } & \multicolumn{3}{|c|}{$\mathrm{B}$} & \multicolumn{3}{|c|}{$E$} & \multicolumn{3}{|c|}{$G$} \\
\hline & $\mathrm{Ph}$ & $\mathrm{T}\left({ }^{\mathrm{O}} \mathrm{C}\right)$ & $\mathrm{MC}(\%)$ & $\mathrm{Ph}$ & $\mathrm{T}\left({ }^{\circ} \mathrm{C}\right)$ & $\mathrm{MC}(\%)$ & ph & $\mathrm{T}\left({ }^{\circ} \mathrm{C}\right)$ & $\mathrm{MC}(\%)$ & ph & $\mathrm{T}\left({ }^{\mathrm{O}} \mathrm{C}\right)$ & $\mathrm{MC}(\%)$ \\
\hline 10 & 4.2 & 60 & 18 & 4 & 55 & 15 & 4.2 & 50 & 18 & 4.3 & 52 & 15 \\
\hline 100 & 5 & 46 & 26 & 5.1 & 41 & 21 & 5.2 & 41 & 25 & 5 & 40 & 20 \\
\hline 200 & 6.1 & 33 & 35 & 6.3 & 32 & 35 & 6.3 & 31 & 34 & 6.3 & 31 & 31 \\
\hline Control & 6.6 & 30 & 45 & 6.7 & 29 & 41 & 6.6 & 30 & 40 & 6.7 & 29 & 35 \\
\hline
\end{tabular}

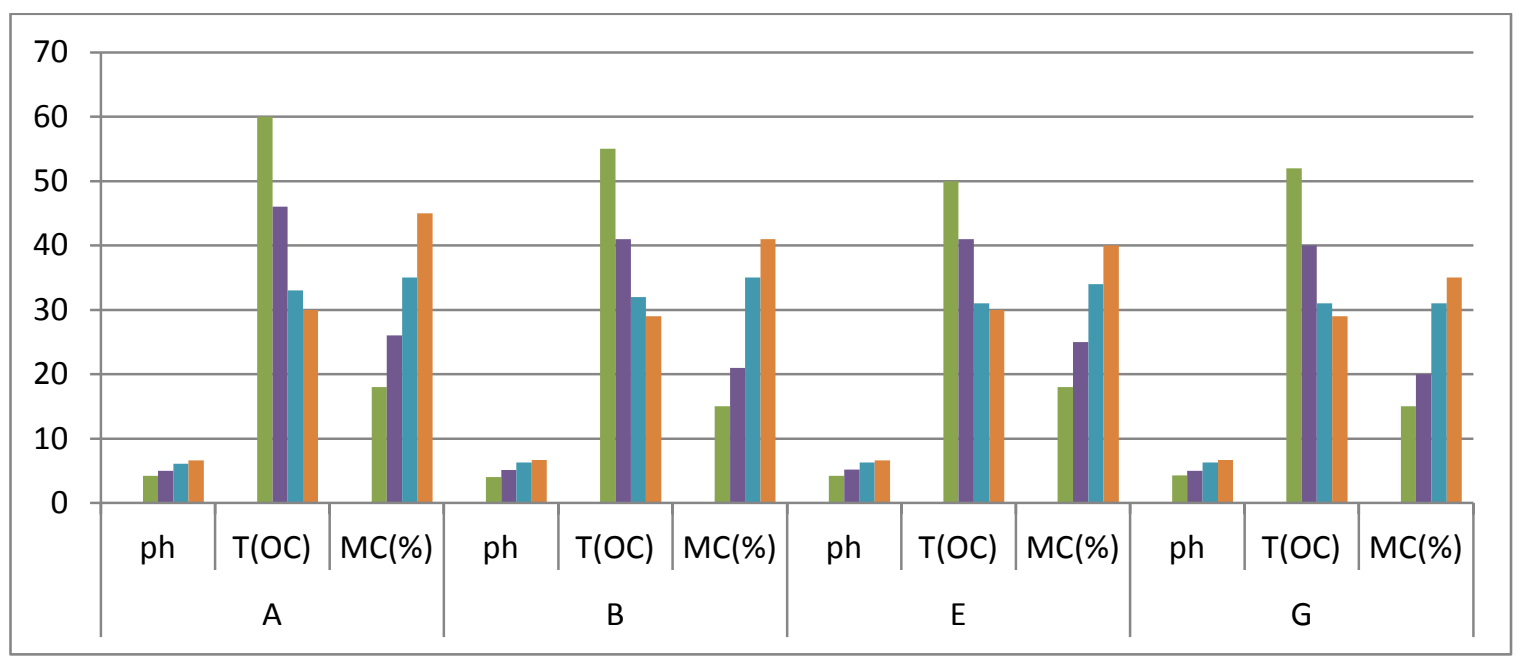

Fig 2: The ph, temperature and moisture content of the various soil samples taken from gas flare locations a, B, E and $\mathbf{G}$ 
Am. J. Sci. Ind. Res., 2013, 4(2): 246-252

Table 3: Bacteria counts of the soil samples in relation to distance from flare point

\begin{tabular}{|l|l|l|l|l|l|}
\hline Bacteria counts & & $\mathbf{1 0 m}$ & $\mathbf{1 0 0 m}$ & $\mathbf{2 0 0 m}$ & control \\
\hline \multirow{3}{*}{$\begin{array}{l}\text { Petroleum degrading } \\
\text { Bacteria (cfu/g) }\end{array}$} & $\mathbf{A}$ & $1.1 \times 10^{2}$ & $2.1 \times 10^{2}$ & $3.9 \times 10^{4}$ & $4.2 \times 10^{4}$ \\
\cline { 2 - 6 } & $\mathbf{B}$ & $1.0 \times 10^{2}$ & $2.4 \times 10^{3}$ & $4.3 \times 10^{4}$ & $4.6 \times 10^{4}$ \\
\cline { 2 - 6 } & $\mathbf{E}$ & $0.8 \times 10^{2}$ & $2.0 .10^{3}$ & $3.4 \times 10^{4}$ & $3.6 \times 10^{4}$ \\
\cline { 2 - 6 } & $\mathbf{G}$ & $0.7 \times 10^{2}$ & $1.3 \times 10^{3}$ & $6.2 \times 10^{4}$ & $6.6 \times 10^{4}$ \\
\hline $\begin{array}{l}\text { Total heterotrophic } \\
\text { Bacteria (cfu/g) }\end{array}$ & $\mathbf{A}$ & $1.1 \times 10^{2}$ & $5.1 \times 10^{3}$ & $5.1 \times 10^{4}$ & $3.3 \times 10^{5}$ \\
\cline { 2 - 6 } & $\mathbf{B}$ & $1.2 \times 10^{2}$ & $6.0 \times 10^{3}$ & $4.3 \times 10^{5}$ & $4.8 \times 10^{5}$ \\
\cline { 2 - 6 } & $\mathbf{E}$ & $1.4 \times 10^{2}$ & $5.3 .10^{3}$ & $2.2 \times 10^{5}$ & $2.6 \times 10^{5}$ \\
\cline { 2 - 6 } & $\mathbf{G}$ & $1.2 \times 10^{2}$ & $1.7 \times 10^{3}$ & $2.2 \times 10^{4}$ & $3.0 \times 10^{5}$ \\
\hline \multirow{3}{*}{$\begin{array}{l}\text { Botal coliform } \\
\text { Bacteria (cfu/g) }\end{array}$} & $\mathbf{A}$ & $0.4 \times 10^{2}$ & $1.6 \times 10^{3}$ & $3.6 \times 10^{4}$ & $4.1 \times 10^{4}$ \\
\cline { 2 - 6 } & $\mathbf{B}$ & $0.2 \times 10^{2}$ & $1.7 \times 10^{3}$ & $3.3 \times 10^{4}$ & $3.9 \times 10^{4}$ \\
\cline { 2 - 6 } & $\mathbf{E}$ & $0.5 \times 10^{2}$ & $2.1 .10^{3}$ & $1.1 \times 10^{5}$ & $2.3 \times 10^{5}$ \\
\cline { 2 - 5 } & $\mathbf{G}$ & $0.4 \times 10^{2}$ & $1.8 \times 10^{3}$ & $4.9 \times 10^{4}$ & $6.1 \times 10^{4}$ \\
\hline
\end{tabular}

Table 4: The mean noise level values recorded from some company's gas flare locations

\begin{tabular}{|l|l|l|l|l|}
\hline & \multicolumn{5}{|l|}{ MEAN NOISE LEVEL VALUES AT 75m FROM THE FLARES dBA } \\
\hline COMPANY & LOCATION & Mean Value & Range & DPR Limit (Lower-Upper) \\
\hline A & A1 & 81.4 & $61.7-97.0$ & $80-100$ \\
\hline & A2 & 46.8 & $32.4-53.6$ & $80-100$ \\
\hline & A3 & 74.3 & $62.7-87.6$ & $80-100$ \\
\hline B & B1 & 63.6 & $61.0-65.4$ & $80-100$ \\
\hline & B2 & 69.8 & $59.2-97.3$ & $80-100$ \\
\hline C & C1 & 59.9 & $49.7-68.4$ & $80-100$ \\
\hline & C2 & 67.6 & $60.2-76.6$ & $80-100$ \\
\hline & C3 & 61.9 & $61.0-77.5$ & $80-100$ \\
\hline D & D1 & 65.6 & $61.1-78.0$ & $80-100$ \\
\hline E & E1 & 65.5 & $65.2-95.8$ & $80-100$ \\
\hline & E2 & 73.7 & $58.1-77.6$ & $80-100$ \\
\hline F & F1 & 86.5 & $52.7-96.1$ & $80-100$ \\
\hline & F2 & 65.1 & $61.5-79.3$ & $80-100$ \\
\hline & F3 & 57.3 & $50.1-73.0$ & $80-100$ \\
\hline G & G1 & 80.9 & $67.7-85.4$ & $80-100$ \\
\hline H & H1 & 65.5 & $59.4-80.8$ & $80-100$ \\
\hline & H2 & 79.5 & $61.1-98.9$ & $80-100$ \\
\hline I & I1 & 89.5 & $76.6-93.7$ & $80-100$ \\
\hline & I2 & 57.6 & $45.9-76.4$ & $80-100$ \\
\hline & I3 & 89.7 & $77.2-98.1$ & $80-100$ \\
\hline J & J1 & 49.8 & $45.6-53.4$ & $80-100$ \\
\hline & J2 & 57.1 & $53.2-68.8$ & $80-100$ \\
\hline K & K1 & 68.3 & $60.4-78.9$ & $80-100$ \\
\hline & K2 & 71.2 & $68.1-76.5$ & $80-100$ \\
\hline
\end{tabular}




\section{CONCLUSION}

The results obtained under environmental analysis showed that the $\mathrm{pH}$ of rainwater $(<5.6)$ were not within regulation limits for most gas flare location. In addition, the average of soil temperature $\left(54^{\circ} \mathrm{C}\right.$ and $42^{\circ} \mathrm{C}$ ) as against $30^{\circ} \mathrm{C}$, soil $\mathrm{pH}$ of $(4.1-5.1)$ as against 6.7 and the low soil moisture content of $(17 \%-23 \%)$ as against $40 \%$ for the $(10 \mathrm{~m}$ and $20 \mathrm{~m})$ and control. The general result obtained from bacteria count test shows great reduction in the soil bio load at the $10 \mathrm{~m}$ and $100 \mathrm{~m}$ distance from the flare point. All result recorded during this extensive research study of the producing oil community of Niger Delta environment do not portray good omen for these communities. The results obtained shows that gas flaring is responsible for the contamination of water bodies which then affects the survival of fishes and other aquatic life. Almost no vegetation can grow in the area directly surrounding the flare due to the tremendous heat it produces and the acid nature of the soil $\mathrm{pH}$. This acid nature of the soil also has attendant effect on the soil usually used in agricultural purposes. Corrugated metal roofing sheets in the vicinity of flare corrode and deteriorate at a very faster rate as against their established life span.

From the results obtained in this study, it is concluded that most of the environmental hazard claims from different indigenes of communities adjacent to gas flare locations are true effects and reflections of the gas flaring activities in these regions.

\section{REFERENCES}

American Public Health Association (1985) Standard Methods for the Examination of Waste water. $15^{\text {th }}$ Edition Washington D.C.
Amund, O.O., Adebowale, A.A, and Ugorji, E.O. (1987) "Occurrence and Characteristics of Hydrocarbon Utilizing Bacteria in Nigerian soils contaminated with spent motor oil". Indian Journal of Microbiology. 27: 134-143.

Bezharauh, R.H., Gogoi, B.K. and Pillai, K.R. (1994) Isolation and identification of micro-organisms involved in microbial desulphurization of petroleum crude.Indian Journal of Microbiology. 34: 49-53.

Botkin, D.B. and Keller, E.A. (1998) Environmental Science, Earth as a living planet. $2^{\text {nd }}$ Edition. John Willey and Sons Canada

Chessbrough, M.(1987) "Medical Laboratory Manual for Tropical Countries". $4^{\text {th }}$ Edition Tropical Health Technology and Butterworth, London.

Cowan, S.T. and Steel, K.J. (1976) "Cowan and Steel Manual of Medical Bacteriology". Cambridge University Press, London.

Chilaka, A.C. (2009). "Nigeria gas transmission tariff framework study." Industrial Thesis, Centre for oil and gas Technology Institute of Petroleum Studies University of Port Harcourt

Energy Information Administration (EIA) 2006 "Nigeria country analysis brief."United States department of energy Washington D.C.

Manby, B. (1999) "The price of oil: corporate responsibility and human rights violations in Nigerians oil producing communities." Human Right Watch New York 202pp.

Onyekonwu, M. (2008) "Best practices and policies- the Nigerian oil and gas industry policy problems." Port Harcourt petroleum review, vol.1 No1 14pp.

Prescot, L.M, Harly, J.P. and Klein, D.A. (1999) Microbiology $4^{\text {th }}$ edition, WCB.McGraw Hill New York, London.

Watts M.(2001). Petroleum violence: communities, extraction and political ecology of a mythic commodity.189-212pp. Cornell University Press 